\title{
Determinants of the Net Interest Margins in BH Banks
}

\author{
Article history: \\ Received: 13 January 2015 \\ Sent for revision: 3 February 2015 \\ Received in revised form: 8 March 2015 \\ Accepted: 16 March 2015 \\ Available online: 1 April 2015
}

\begin{abstract}
In this paper, the subject of analysis is influence of certain macroeconomic and microeconomic variables on bank net interest margins in Bosnia and Herzegovina (BH) for the period from 2008 to 2013 through a multiple linear regression models. The level and dynamics of NIM indicate the efficiency of financial intermediation. The observed period is characterized by the reduction in net interest margins of banks over the previous decade, which was characterized by high GDP growth, bank loans and high-interest rates and high profitability. Therefore, this study examines the factors that affect the level of net interest margins in the domestic banking industry. The main objective of this paper is to determine whether there is interdependence in the movement between the independent and dependent variables through a multiple linear regression. The net interest margin will be observed as a dependent variable, and liquidity risk, operating costs, credit risk, the index of market concentration, funding risk, the growth rate of gross domestic product and consumer price index will be used as independent variables.
\end{abstract}

Key words: net interest margin, efficiency of financial intermediation, interest rate spread, banks operating costs.

\section{Determinante neto kamatnih margina za banke u BiH}

Rezime: Predmet istraživanja u ovom radu je analiza uticaja pojedinih makro ekonomskih i mikroekonomskih varijabli na neto kamatne margine banaka u

\footnotetext{
${ }^{1}$ University of East Sarajevo, Faculty of Economics, Republic of Srpska, novoplakalovic@gmail.com

2 University of Zenica, Faculty of Economics, Bosnia and Herzegovina 
Plakalović N., Alihodžić A.: Determinants of the Net Interest Margins in BH Banks

Bosni i Hercegoviniza period od 2008 do 2013., uz primenu modela višestruke linearne regresije. Nivo $i$ dinamika neto kamatnih margina ukazuju na efikasnost u finansijskom posredovanju. Posmatrani period karakteriše smanje nje neto kamatnih margina banaka u odnosu na raniji period koji je bio karakterističan po visokom rastu bruto domaćeg proizvoda, bankarskih kredita, kamatnih stopa i visoke profitabilnosti. Stoga, ovo istraživanje ispituje faktore koji utiču na nivo neto kamatnih margina u domaćem bankarskom sektoru. Osnovni cilj ovog istraživanja je da se utvrdi da li postoji međuzavisnost u kretanju između nezavisnih I zavisnih varijabli kroz primenu modela višestruke linearne regresije. $U$ ovom istraživanju neto kamatna margina će se posmatrati kao zavisna varijabla, a rizik likvidnosti, operativni troškovi, kreditni rizik, indeks tržišne koncentracije, rizik finansiranja, stopa rasta BDP-.a iindeks potrošačkih cijena će se posmatrati kao nezavisne varijable.

Ključne reči: neto kamatne margine, efikasno finansijsko posredovanje, kamatni spread, operativni troškovi banaka.

\section{Introduction}

During the last two decades, Bosnia and Herzegovina $(\mathrm{BH})$ has made radical changes in the banking sector. The financial system is liberalized, banks are almost completely privatized, and a system of banking regulation and supervision has been introduced. Regulatory Agencies (Banking Agency of Federation of Bosnia and Herzegovina, Banking Agency of Republic of Srpska) have been founded as independent institutions with the aim to ensure the safety of the financial sector which is largely represented by banks. Regulation and supervision are based on risk oversight.

The reforms contributed to significant financial deepening so that the net interest margin (NIM) narrowed down in the past few years. High-interest margins are influenced by the strengthening of the equity capital of banks. Banks in Bosnia and Herzegovina (BH) can be considered well capitalized. On the other hand, although one might expect, that the high-interest margins adversely affect the domestic real savings and investments, it did not happen. There was a significant increase in savings and investment in $\mathrm{BH}$, especially before the global financial crisis in 2008, after which economic stagnation followed. The high growth of savings in 2008 occurred due to the gradual return of trust in the domestic banking system and the previous collapse of the financial and banking system during the conflicts in Bosnia and Herzegovina from 1992 to 1995. Growth of savings in the banks contributed to the evident 
results in macroeconomic stabilization due to the introduction of the currency board in 1997, contributing to a significant stabilization of prices. A specific system of monetary control and the absence of the "lender of last resort" with the Central Bank, the dominance of bank credit as a source of financing in the context of an underdeveloped financial system, fluctuations in capital flows in and out of the country and the exposure of the domestic economy to external shocks, indicate high risk being obvious in the financial system of $\mathrm{BH}$.

The NIM level and dynamics indicate the efficiency of financial intermediation. High-interest margins indicate inefficient and costly intermediation of banks that discourages investment and strengthening of domestic savings. The presence of foreign capital through investment and the dominant presence of international banks in the domestic financial market would, as expected, promote the efficiency and competitiveness of the domestic financial system and consequently increase the efficiency of financial intermediation. Therefore, this paper analyzes the impact of the share of foreign banks in the domestic banking market.

From the review of the empirical sources that deal with determiners of net interest margins of banks we have found that research focuses on microeconomics, its specifics, and macroeconomic variables. The microeconomic factors that affect the net interest margin consist of: operating costs, credit risk, liquidity risk, credit quality, interest rate risk, opportunity costs of bank reserves, capital adequacy, quality of bank funding, bank size, ownership structure. The most significant changes in the macroeconomic factors are the changes in GDP and inflation.

Inflation and real GDP growth are considered the most important factors within the policy in the forefront of entry regulation and the degree of concentration or degree of competition in the banking market. Undivided opinion is that inflation has a positive impact on the growth of net interest margin, while the GDP impact is ambiguous. Effect of GDP can be different in relation to the phase of the cycle.

During the economic growth and increased demand for loans, net interest margin can grow while good economic performance reduces the risk of bank defaults. On the other hand, during recessionary trends in the economy due to a lack of creditworthy borrowers interest rates may rise.

In this research, we started from the cost function model of Klein M. (1971) and Nassaret et al. (2014). The studies show that operating costs are the most important driving factor of banks interest net margins. There was a 
significant effect liquidity risk and inflation on the net interest margin, while the impact of real GDP growth is weak.

According to Plakalovic N. (2014.), the interest margins of smaller banks (usually locally-owned) are noticeably higher compared to the large foreignowned banks that are subsidiaries of international banks. Increasing funding by parent banks impacts NIM of banks with foreign ownership- positively. This suggests that foreign-owned banks are under pressure to reduce operating costs in order to offer more competitive interest margins.

With a cumulative test, it is assumed in a null hypothesis that all independent variables equal zero, i.e. that not a single independent variable included in the model is significant in this model. An alternative hypothesis assumes that at least one of the important independent variables is important in the model.

This research is designed and presented in four sections. The first part reviews the relevant literature, the second part presents the background of institutional banking sectors, the third part describes the theoretical assumptions and perceptions, the regression model and gives a definition of significant independent variables that affect the net interest margin alone whereas the last part of the paper discusses the results of research, based on the application of the regression model. This research will test the significance of observed financial variables in the model, where the null hypothesis is the reason the independent variables do not significantly affect the dependent ones. In this context, it is stated that the observed independent variables have the greatest impact on the growth or decline rate of net interest margin for the banking system in $\mathrm{BH}$. Finally there are few interesting concluding remarks.

\section{Literature Review}

Net interest margins are a significant indicator of the efficiency of the banking financial intermediation. It is believed that the key competitiveness factors that lower the net interest margin (NIM) are relatively high in Bosnia and Herzegovina. It is a fact though that there was a slight lowering of net interest margin, but the decline has been significantly slowed down. The general opinion is that the net interest margin is higher in less developed countries (than in developed countries where NIM is relatively low). Common reasons for this are found in the lack of competition, higher costs and intermediation response to changes in regulation.

Levels of net interest margin in the banking systems of some groups of countries and their comparative analysis aims to point out the causes and 
factors that influence the levels of net interest margin by banking systems of individual countries or banking systems group of countries

In general, the level of net interest margin is primarily a consequence or result of the level of development and competitiveness of the financial system of the country. Efficient financial intermediation allows easier and more convenient financing of the local economy and creates favorable conditions for dynamic economic growth.

Numerous studies show several factors that affect the level of the interest margin in the banking industry of individual countries. They can be grouped into basic groups of factors such as specific factors, market structure, and macroeconomic factors. Demirgüç-Kunt A. and HuizingaH. (1999) found that at the international level, the size of banks, credit risk and liquidity risk affect the net interest margin. On a sample of six European countries and banks in the United States, Saunders, A. and Schumacher, L. (2000) found a significant trade-off between ensuring banking solvency (the rate of capital relative to assets) and lowering the cost of financial services clients, which leads to lower interest margins.

On a sample of US banks, Carbó V. and Rodríguez F. (2007) reveal that credit risk and liquidity risk increase interest margin. They also indicate that the relationship between interest margin and market power significantly varies according to banking specialization and that the market power increases as banking activities become more diversified towards non-traditional banking activities (including non-interest income). The regulation of bank entry, market structure and market transparency and informing borrowers affect the efficiency of financial intermediation.

More segmented markets are usually associated with a high market power and influence of the increase in the interest margin, as found by Saunders A. and SchumacherL. (2000). In the same study, the authors analyze macroeconomic factors and reveal that the volatility of interest rates generally affects the increase in interest margins. Interest margins are determined by premiums for credit risks and macroeconomics. A study of Claeus S., Vander Venne R. (2008) shows increased efficiency in financial intermediation, expressed through lower interest margins present, in Eastern European countries that joined the European Union, more frequent and higher than in those countries that did not join the EU.

Analysis of 1.400 banks in 72 countries showed that restrictive regulation of banks entering the market and tight regulation of banking activities raise the cost of financial intermediation. Inflation has a strong positive impact on NIM 
and higher costs (overhead costs) and a higher degree of concentration in the banking sector accompanied by a higher level of interest margin (DemirgüçKunt, A., Laeven, L., Levine, R., 2003).

The low net interest margins, rising profitability and declining stability of the banking sector of countries with high income countries are characterized by the latest boom of the finance sector in these countries immediately before the economic crisis in 2007. (Beck T., Demirgüç-Kunt A. Levine R. 2009)

The survey of 456 banks in 41 countries in Africa has shown that competition is positively followed with interest margins again depending on the level of efficiency of individual banks. Increased competition and lower market concentration reduce interest margins. Efficient banks increase their interest margins in more concentrated markets. (Ahokpossi C., 2013, 12.)

According to the study of Sensarma R. and Ghosh, S (2004, 41-47)the nature of ownership (both private or public) significantly determines net interest margin of banks in India. Net interest margin in banks of India is linked to the size of a bank, the proportions of non-interest income has no impact on the net interest margin, the proportion of investments in government securities having the opposite effect on net interest margin, higher rate of capital goes with higher NIM, higher rates of nonperforming assets (NPA) goes to the lower net interest margin(NIM), and foreign banks have higher net interest margin (NIM).

The research of microeconomic and macroeconomic determinant of net interest margin in Brazilian banks has shown that the most important roles are played by the inflation rate, risk premium, the economic activity, the reserve requirement (macroeconomic factors) and CAMEL-type indicators (microeconomic factors). They concluded that macroeconomic factors were the most significant and best explained the net interest margin in Brazil (Afanasieff T.S. Lhacer P.M.V. Nakane I.M., 2002).

Research of the financial intermediation costs in low-income countries compared to emerging markets is that constantly higher costs of intermediations in these countries can largely be explained by factors specific to banks. Margins tend to rise with the increase in the insecurity of the loan portfolio, lower banks' capitalization and small size banks. It was found that markets, structured with a higher concentration and a lack of competition in the banking systems of low-income and institutional weaknesses include key constraints to reduce the costs of mediation. With regard to the policies, it is suggested to strengthen banking competition and the institutional basis that would reduce the cost of intermediation in low-income countries. Studies in 
countries with lower income levels and in developed and richer countries reach similar results in terms of effects of competition and market concentration at the level of the interest margin on given banking markets.

This topip was not sufficiently researched in Bosnia and Herzegovina. The first such study was recently published by Plakalovic, N. (2014), which showed a decline in interest spread from 2008 to 2013 as a turning point in the economic growth of BH. GDP growth slowed down after 2008 with even some negative growth in some years as a result of the spillover of the economic crisis in Bosnia and Herzegovina. Apparent is the size and dispersion interest spread on individual banks.

\section{Institutional background}

After decades of tradition "socialist banking“, in the early years of the millennium the banks in $\mathrm{BH}$ were privatized. The financial system was radically reformed, liberalized and turned with international capital flowing in. International banks, mainly from Austria, Germany, Croatia, and Italy entered the market through the acquisition of domestic banks. Private sector owned $94 \%$ of bank capital the state - owned only $6 \%$. Currently in BH, there are 29 banks. As of the private banks, about $90 \%$ of their capital is foreign owned. All large and larger banks are foreign-owned. The market in $\mathrm{BH}$ is small, with about 3.8 million inhabitants and GDP in 2013 amounted to 17.7 billion USD. The banking sector is relatively large, with assets equivalent to $90 \%$ of GDP. Credit to the private sector amounted to $29 \%$ of GDP, which indicates a very weak business sector. Money in the broadest category of M2 is about $62 \%$ compared to the amount of GDP. The financial system consists of commercial banks, micro-credit institutions, leasing companies. Over 95\% of assets in financial institutions is dedicated to commercial banks, are dominant institutions and practically only provide loans to private companies. Microcredit organizations granted a large number of small loans to individuals and micro enterprises that do not have credit ratings. Most resources of banks were mobilized through the collection of domestic deposits.

Foreign sources of funds (mainly from parent banks) in 2007 accounted for $30 \%$ of total funds until after the crisis in 2008, when foreign liabilities (foreign deposits and loans) fell to $15 \%$. Demand deposits represent $25 \%$ of the funds and time deposits $35 \%$ of total sources of funds. The total time deposits in the household sector are related to $72 \%$ of deposits. Deposits in Euro (euroization) are $47 \%$ of total deposits. Bank reserves (required reserves and excess reserves) in 2007 stood at $20 \%$ of total assets and $16.4 \%$ in 2013 
which are still very high volumes of disbursed funds based on which banks suffer significant opportunity costs. The reason for the retention of an excessive volume of liquid assets is poor functioning of the interbank market and the money market in general and the lack of lending function by the Central Bank of Bosnia and Herzegovina prohibited by the law in the context of the currency board arrangement. Flows of funds usually go to parent banks and subsidiary banks in $\mathrm{BH}$. In recent years, the central government has issued treasury bills so that banks now have assets of about $5 \%$ of government securities (www.cbbih.ba).

Regulatory authorities are trying to ensure the safety of the banking system through the insistence on maintaining the high capitalization of banks. Regulatory capital adequacy standard in BH is $12 \%$ of capital relative to riskweighted assets. Banks retain more of the required capital ratios, and capital adequacy is assessed to be appropriate. In 2007, the rate of capital relative to total assets ratio was $10 \%$ and by the end of 2013 it risen to $14.3 \%$. Banking regulations are quite rigid in an effort to prevent banks from entering the outrageous moral hazard. The preparation for the implementation of Basel II standards in undergoing a number of banks.

Information asymmetry is present in banking, moral hazard, with weak and slow judicial practice of resolving disputes. Banks offer a variety of interest rates on time deposits of up to three years ranging from $1.7 \%$ to $5.7 \%$. Clients do not worry about creditworthiness of the bank nor about the quality, because, the Agency for Deposit Insurance - provided the banks with deposits amounting to 25. 000,00 EUR, (with only a single bank excluded) in January 2014.Interest on loans for general consumption ranges from $14.1 \%$ to $3.5 \%$. This is quite unusual, especially the fact that banks that have offices for example in the same street offer the same kind of interest on loans with its level varying up to $50 \%$. This can be interpreted partially by the following: due to a lack a lack of financial literacy, their clients "insensitivity", the level of interest rates primarily due to poor credit standing and thus the willingness to accept any interest rate (Plakalovic, N. 2011). Usually, banks offer highinterest rates on time deposits and loans granted simultaneously with the highest interest rates. The worst banks rates maximized time - deposits by $72 \%$ for the last 4 years due to their high interest (Krunic, G. 2014).

\section{Data analysis and methodologies}

The research will use the cost function model whereas operating costs are the most important driving factor of banks interest net margins. The data used for 
this study are the official data published by the Central Bank of $\mathrm{BH}$ and Banking Agency of the FBH and the Banking Agency of the Republic of Srpska, from the period: 2008 - 2013. The research will also use the statistical package SPSS 16.O. The net interest margin will be observed as a dependent variable. The independent variables are as follows:

$r_{A}-r_{P}=L R+O C+C R+H H I+F R+R G D P+I N F L$

with:

$L R$ - liquid reserves + short-term securities / assets;

$O C$ - operating expenses from the income statement of banks / assets;

$C R$ - total provisions for losses / loans;

$H H I$ - coefficient of concentration in the market;

$F R$ - risk of acquiring funds is calculated: total loans / total deposits;

$R G D P$ - real GDP growth in\%;

$I N F L$ - the price index in \%.

The regression model is an equation with a finite number of parameters and variables. Depending on whether a model comprised only one or more variables, there are simple and multiple linear regression models respectively. In addition to a dependent variable and one or more independent variable, each regression model contains a random variable. A simple linear regression model expresses a relationship between the two parameters as follows:

$$
Y_{i}=\alpha+\beta X_{i}+\varepsilon_{i} \quad i=1,2, \ldots \ldots n,
$$

where:

$Y$ - dependent variable,

$\alpha i \beta$ - unknown parameters that need estimate, and

$\varepsilon_{i}-$ stochastic variable(error distances)

Unlike the simple regression, the multiple-linear regression model is different in that it comprises two or more independent variables.

$Y_{i}=\alpha+\beta_{1} X_{i, 1}+\beta_{2} X_{i, 2}+\cdots+\beta_{i} X_{i, j}+\cdots+\beta_{k} X_{i, k}+\varepsilon_{i}$

$i=1,2, \ldots . n$.

Specifically, this model consists of independent variable $\mathrm{Y}$, and $\mathrm{K}$ independent variables, which are referred to as: $X_{-}(\mathrm{i}, \mathrm{j})=1,2, \ldots \ldots, \mathrm{K}$. 
This empirical study refers to the net interest margin of the banking sector in $\mathrm{BH}$ for the period from 2008 to 2013. The data used for this study are the official data (statistical analysis) of the Central Bank of Bosnia and Herzegovina and Banking Agency of the Federation of Bosnia and Herzegovina (FBH) and the Banking Agency of the Republic of Srpska.

This study used a multiple-linear regression model that assesses the nature and strength of the bond between a dependent variable, and $\mathrm{K}$ independent variables that are marked with $X_{-}(i, j)=1,2, \ldots . ., K$. Therefore, in this study, net interest margin of the banking sector in BH (NIM) is used as dependent variable, and the following ones as independent variables: liquidity risk (LR), operating costs $(\mathrm{OC})$, credit risk (CR), the index of market concentration $(\mathrm{HHI})$, funding risk (FR), the growth rate of gross domestic product (RGDP) and consumer price index (CPI).

Table 1. Descriptive explanation of the variables in the model

\begin{tabular}{|c|c|c|}
\hline Variable & Symbol & Description \\
\hline $\begin{array}{l}\text { Net interest } \\
\text { margins }\end{array}$ & NIM & $\begin{array}{l}\text { Net interest income as a percentage of } \\
\text { interest earning assets }\end{array}$ \\
\hline Liquidity risk & LR & $\begin{array}{l}\text { Current assets -to - current liabilities (classic } \\
\text { indicator of funding liquidity risk ) }\end{array}$ \\
\hline $\begin{array}{l}\text { Operating } \\
\text { costs }\end{array}$ & $\mathrm{OC}$ & Operating costs-to-total earning assets \\
\hline Credit risk & $\mathrm{CR}$ & $\begin{array}{l}\text { Lagged ratio of loan loss provisions-to total } \\
\text { loans and advances }\end{array}$ \\
\hline $\begin{array}{l}\text { Market } \\
\text { concentration }\end{array}$ & $\mathrm{HHI}$ & Herfindahl-Hirschman Index \\
\hline Funding risk & FR & Credit-to-deposit ratio \\
\hline $\begin{array}{l}\text { Real GDP } \\
\text { growth }\end{array}$ & RGDP & Real GDP growth \\
\hline $\begin{array}{l}\text { Consumer } \\
\text { Price Index }\end{array}$ & $\mathrm{CPI}$ & Consumer Price Index \\
\hline
\end{tabular}

Source: authors

Net interest margin - NIM - expressed as a ratio to total interest income minus interest paid in relation to interest bearing assets. Interest bearing assets are calculated by dividing the total assets of banks seize cash and required reserves (funds) and fixed assets (buildings, etc.) and other assets that do not carry the offering. Interest margin represents the cost that banks charge to their financial intermediation. 
Liquidity risk-LR - The risk of insolvency is the inability of banks to meet maturing obligations that may eventually lead to loss of business. As a measure of liquidity risk, the ratio of loans to deposit is most commonly used. In order to reduce the liquidity risk, banks hold a greater amount of liquid assets, which can be easily converted to cash. On the other hand, liquid agents have lower yields resulting in lower profitability. Thus, the high liquidity (lower loan-to-deposit ratio) leads to low profitability, and vice versa: lower liquidity (higher ratio of loans/deposits) leads to greater profitability (Kosmidou,K. 2008).

Operating costs - OC - Operating costs are measured as the rate of operating expenses to total assets. Less efficient banks have higher operating costs and are expected to transfer them to their customers through higher margins. In some studies, the operating costs are used as the dependent variable so that they could analyze the determinants of the efficiency of financial intermediation services (Demirgic-Kunt at all. 2004).

Credit risk -CR -the higher demand for greater margins of the banks that would participate in such projects, the higher the credit risk associated with financial intermediation demands. For risky projects, banks must charge higher interest rates as the risk premium. The risk loans must be ensured with greater reserves that banks set aside from the productive resources. As an indicator of risk volume of write-offs of bad loans, the volume of delinquent loan portfolio or reserves for bad loans can be used. The problem is that these indicators say about the past rather than the future. In this study, we will use them for measuring credit risk rate loan loss reserves in relation to loans.

The index of market concentration - $\mathrm{HHI}$ is a widely accepted measure of market concentration, where the index value is obtained by individual squaring and adding all market shares of each company that participate in the market. The $\mathrm{HHI}$ may take different values in the range from 0 to 10.000 . The concentration index does not increase linearly, which means, for example, if the value is of 3.000 , it means that the concentration in the system is $30 \%$. If the concentration of the index is in the interval from 0 to 1000 which is considered as non - concentrated market, or which means there is a high level of competition. If the index takes values from 1.000 to 1.800 , then we can say that the market presents moderate concentration. Furthermore, if the value of the index is between 1.800 and 10.000 , then the market is concentrated, i.e. there is a monopoly. If concentration index approaches zero value, it means the market has a large number of participants of approximately equal size. $\mathrm{HHI}$ increases when the market reduces the number of companies or if there is disparity in their size. So, with the increase 
in market concentration, competition and efficiency are reduced, which leads to opportunities for monopoly and collusion. $\mathrm{HHI}$ index is expressed as follows:

$$
H=\sum_{i=1}^{N} S_{i}^{2}
$$

where is:

$S_{i}$ - the market share of firm (i) in the market; and

$\mathrm{N}$ - number of firm.

A small index indicates a competitive industry with no dominant players. If all firms have an equal share, the reciprocal of the index shows the number of firms in the industry. When firms have unequal shares, the reciprocal of the index indicates the equivalent number of firms in the industry (http://en.wikipedia.org/).

Funding risk - FR - net interest margins depend on the way of obtaining funds or as funded (funded) lending as well as currency risk. Currency risk in Bosnia and Herzegovina during the previous period was minimized with respect to the effective currency board regime with legally fixed rate for the domestic currency against euro. The study will use an indicator of loan to deposit ratio in order to assess the impact of providing funds to the net interest margin. The high and rising ratio of loans to deposits indicates inflow of foreign capital that leads to an increase if the associated currency risk were adequately internalized. The sudden reversal of these flows out of the country or to foreign countries (a decline in the credit to deposit ratio) would also put pressure on bank's business models and lead to higher interest margins. (Nassar, B.K. Martinez, E., Pineda, A. 2014, p. 8)

The growth rate of gross domestic product - RGDP - economic activity is measured by the growth rate of GDP. The impact of real GDP growth in net interest margin is ambiguous. It is expected that margins will decline in times of high economic growth as banks have more investment opportunities during the economic boom and is expected to raise interest rates on deposits in order to attract more funds needed to finance new projects. The negative effects of real GDP growth in net interest margin during the recession as the creditworthiness of the loan decreases and net worth deteriorate and interest rates can, therefore, increase.

Consumer price index - CPI - inflation is taken as the percentage change in the CPI. Higher inflation introduced economic uncertainty and expected to expand margins. Among the macroeconomic variables besides GDP, inflation 
is the most important factor. The general view is that higher inflation contributes to the spread of net interest margin.

The regression model in this study is presented as follows:

$$
\begin{gathered}
(N I M)=\alpha+\beta_{1} *(L R)+\beta_{2} *(O C)+\beta_{3} *(C R)+\beta_{4} *(H H I)+\beta_{5} \\
*(F R)+\beta_{6} *(R G D P)+\beta_{7} *(C P I)+\varepsilon_{i}
\end{gathered}
$$

The representativeness of the model will examine calculation of the coefficient of correlation $(r)$, coefficient of determination $\left(R^{2}\right)$ and adjusted coefficient of determination $\left(\bar{R}^{2}\right)$. There is also an analysis of variance (ANOVA), which will test the significance of observed financial variables in the model, where the null hypothesis is the reason why the independent variables do not significantly affect the dependent:

$$
\begin{aligned}
& H_{0} \ldots \beta_{1}=0 \\
& H_{1} \ldots \beta_{1} \neq 0
\end{aligned}
$$

The table below illustrates the descriptive statistics of explanatory.

Table2 : Descriptive statistics of the observed banking performance for the period: $2008-2013$

\begin{tabular}{lccc}
\hline $\begin{array}{c}\text { Dependent and } \\
\text { independent variables in } \\
\text { the model }\end{array}$ & Means & $\begin{array}{c}\text { Std. } \\
\text { Deviation }\end{array}$ & $\mathbf{N}$ \\
\hline NIM & 3.53 & 1.57 & 24 \\
LR & 35.01 & 3.62 & 24 \\
OC & 0.93 & 0.45 & 24 \\
CR & 5.05 & 1.77 & 24 \\
HHI & 134.63 & 9.44 & 24 \\
FR & 0.93 & 0.53 & 24 \\
GGDP & 0.15 & 1.24 & 24 \\
\hline
\end{tabular}

Source: Calculation by Author (SPSS 16.0)

The growth in the index of market concentration, as well as the $\mathrm{HHI}$ index showed their highest volatility with a standard deviation of $9.44 \%$ and $5.86 \%$ for the period from 2008 to 2013 year (Table 2). The high volatility of the HHI index creates conditions for oligopoly behaviour of a few large banks in the system, namely around five major banks control almost $80 \%$ of the total assets of the banking sector in $\mathrm{BH}$. Small banks have problems with obtaining 
high-quality long-term sources of funds, problems with recapitalization, problems of independence of foreign banks, and thus, a more difficult access to quality services. A small number of large financial institutions is a general characteristic of the banking market structure, so that free competition is extremely rare in the banking market in $\mathrm{BH}$.

\subsection{The research results}

Results obtained by regression analysis indicated that the coefficient of correlation is $r=0.99$, indicating that there is a strong correlation between the dependent variable, i.e. the net interest margin - NIM and independent variables: liquidity risk (LR), operating costs $(\mathrm{OC})$, credit risk (CR), the index of market concentration $(\mathrm{HHI})$, funding risk (FR), the growth rate of gross domestic product (RGDP) and consumer price index (CPI).

The coefficient of determination is $R^{2}=97 \%$, and the adjusted coefficient of determination is $\bar{R}^{2}=0.96$. The fact shows that this model described $96 \%$ of the variations to the independent variables makes the model relatively representative. The significance test also indicates that there is a substantial influence of certain independent variables on the dependent variable. The testing the null hypothesis of significance obtained statistically significant data indicating that there is significant influence of certain independent variables at a significance level of $\alpha=1 \%$, and that the empirical F-ratio is 89.32. As for this study, the value of the empirical F-ratio (89.32) is greater than the theoretical value of F- ratio (4.03) for the 7-degree of freedom in the numerator and 16 in the denominator, then we come to the conclusion to reject the null hypothesis that the independent variables have a significant impact on the dependent variable. Darbin-Watson statistics show high correlation with respect to the value of approximately 2 .

Table 3. Regression analysis between the following parameters: NIM, $L R$, OC, CR, HHI, FR, RGDP, CPI in BH for the period2008 - 2013

\begin{tabular}{ll}
\hline Regression Statistics & \\
\hline Multiple R & 0.987 \\
R Square & 0.975 \\
Adjusted R Square & 0.964 \\
Std. Error of the Estimate & 0.297 \\
Durbin - Watson & 1.525 \\
\hline
\end{tabular}

Source: Calculation by Author (SPSS 16.0) 
Plakalović N., Alihodžić A.: Determinants of the Net Interest Margins in BH Banks

Table 4. Analysis of variance between the following parameters: NIM, LR, OC, CR, HHI, FR, RGDP, CPI in BH for the period $2008-2013$

\begin{tabular}{lccccc}
\hline ANOVA & Df & SS & MS & F & $\begin{array}{c}\text { Significance } \\
\text { F }\end{array}$ \\
\hline Regression & 7 & 55.410 & 7.916 & 89.32 & 0.001 \\
Residual & 16 & 1.418 & 0.089 & - & - \\
Total & $\mathbf{2 3}$ & $\mathbf{5 6 . 8 2 8}$ & - & - & - \\
\hline
\end{tabular}

Source: Calculation by Author

Table 5. The matrix of correlation coefficients between the parameters: NIM, LR, OC, CR, HHI, FR, RGDP, CPI in BH for the period: $2008-2013$

\begin{tabular}{ccccccccc}
\hline & NIM & LR & OC & CR & HHI & FR & RGDP & CPI \\
\hline NIM & 1.000 & 0.024 & 0.979 & 0.017 & -0.021 & 0.007 & -0.314 & 0.110 \\
LR & 0.024 & 1.000 & 0.091 & -0.835 & 0.907 & -0.818 & 0.221 & 0.766 \\
OC & 0.979 & 0.091 & 1.000 & -0.010 & 0.014 & -0.011 & -0.324 & 0.099 \\
CR & -0.017 & -0.835 & -0.010 & 1.000 & -0.813 & 0.832 & -0.062 & -0.692 \\
HHI & -0.021 & 0.907 & 0.014 & -0.813 & 1.000 & -0.773 & 0.190 & 0.779 \\
FR & 0.007 & -0.818 & -0.011 & 0.832 & -0.773 & 1.000 & -0.340 & -0.786 \\
RGDP & -0.314 & 0.221 & -0.324 & -0.062 & 0.190 & -0.340 & 1.000 & 0.189 \\
CPI & 0.110 & 0.766 & 0.099 & -0.692 & 0.779 & -0.786 & 0.189 & 1.000 \\
\hline
\end{tabular}

Source: Calculation by Author (SPSS 16.0)

The coefficient of correlation can take values from -1 to +1 . Thus, the resulting ratio shows the strength of the two observed parameters. A value of zero indicates that there is no correlation, while the value of 1.0 indicates the correlation between complete and connected, and the value of -1.0 indicates the correlation between complete and negative. The table above clearly shows that most of the explanatory variables are slightly negatively correlated, and on the other hand, it shows that the small number of observed variables have a positive correlation.

Given the case analysis of the influence of independent variables on the dependent variable, and the net interest margin, it can be seen that the strongest positive correlation was observed between the net interest margin and the operating cost $(0.98)$. This positive correlation between net interest margin and operating cost is quite reasonable and logical, because the operating costs are the most important determinants of net interest margins of banks. For example, banks that focus more on retail operations typically face 
higher operating costs than banks that are primarily oriented towards the market. Furthermore, deficiencies in the legal system can serve to increase the cost of credit which is indirectly reflected in the operating costs.

Also, between the net interest margin and the consumer price index recorded a positive correlation (0.110). Likewise, net interest margin and liquidity risk was observed positive causality of the observed period (0.024). Explanation for the positive correlation between net interest margin and liquidity risk lies in the fact that if banks have greater liquidity ratio, or more liquid assets you have less liquidity risk, which in turn leads to an increase in the opportunity cost of holding liquid assets that initiates that banks charge higher spreads. Observed on the other hand, the strongest negative correlation was observed between the net interest margin - NIM and real GDP growth $(-0.314)$.

Table6. Regression analysis coefficients between the following parameters: NIM, LR, OC, CR, HHI, FR, RGDP, CPI in BH for the period: $2008-2013$

\begin{tabular}{|c|c|c|c|c|c|c|c|c|c|c|}
\hline $\begin{array}{l}\overline{0} \\
\frac{0}{2} \\
\Sigma\end{array}$ & 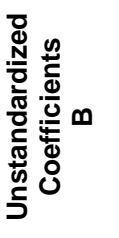 & 它肎 & 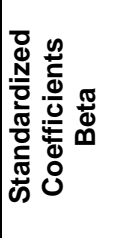 & - & $\frac{0}{n}$ & 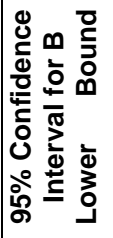 & 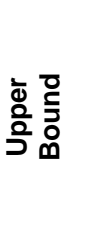 & $\begin{array}{l}\frac{\grave{d}}{0} \\
\frac{0}{0} \\
\frac{0}{0} \\
\text { N }\end{array}$ & 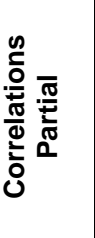 & $\frac{\frac{\pi}{\sigma}}{0}$ \\
\hline (Constant) & -0.521 & 4.001 & - & -0.130 & 0.898 & -9.02 & 7.98 & 0.02 & -0.55 & -0.10 \\
\hline LR & -0.127 & 0.048 & 0.293 & -2.645 & 0.018 & -0.229 & -0.025 & 0.024 & -0.552 & -0.104 \\
\hline OC & 3.434 & 0.153 & 1.003 & 22.517 & 0.001 & 3.111 & 3.758 & 0.979 & 0.985 & 0.889 \\
\hline CR & -0.073 & 0.085 & 0.083 & -0.863 & 0.401 & -0.253 & 0.106 & 0.017 & -0.211 & -0.034 \\
\hline HHI & 0.011 & 0.017 & -0.063 & 0.613 & 0.549 & -0.026 & 0.047 & -0.021 & 0.151 & 0.024 \\
\hline FR & 0.354 & 2.910 & 0.012 & 0.122 & 0.905 & -5.815 & 6.522 & 0.007 & 0.030 & 0.005 \\
\hline RGDP & 0.047 & 0.065 & -0.037 & 0.722 & 0.481 & -0.091 & 0.185 & -0.314 & 0.178 & 0.029 \\
\hline CPI & 0.035 & 0.020 & 0.132 & 1.802 & 0.090 & -0.001 & 0.08 & 0.110 & 0.411 & 0.071 \\
\hline
\end{tabular}

Source: Calculation by Author (SPSS 16.0)

From the table above it is clear that the return on average assets - the NIM has the strongest positive linear relationship to the operating cost - OC (1.003), followed by liquidity risk - LR (0.293), then with the consumer price index - CPI (0.132) and the credit risk - CR (0.083). On the other hand, the weakest linear relationship was observed between the net interest margin and real gross domestic product $(-0.037)$, and the degree of market concentration - $\mathrm{HHI}(-0.063)$. 
Since credit risk is the probability that the debtor will not perform its obligations under the loan and it is expected that the portfolio credit risk in pushing credit margin, due to the intensive use of bank resources to servicing high-risk loans, therefore the greater the likelihood of default leads to an increase in the risk premium on the rate of the loan. In terms of correlation between net interest margin and the consumer price index results are mixed.

According to Pineda D. (2010) and Nassar at al. (2014) operating costs, are significantly and positively correlated with net interest margins. Similarly to these studies, these coefficients are highest among other explanatory variables.

In our present case high operating costs are expected because the banks as almost the only institutions, are engaged in collecting savings and granting loans work retail jobs that require high operating costs in servicing a large number of small customers (a large number of offices, equipment, employees, etc.). Then there are the costs of monitoring the borrower. These increased costs are usually poured into a higher spreads. Institutional weaknesses and weak legal systems increase the risks of credit operations, which make them more expensive. Operating expenses reflect the lower efficiency of the management and organizational structure.

Liquidity ratio is correlated with net interest margins. This is in line with expectations as the bank (its liquidity) risks by trying to shift the clients through the interest margin. Although the coefficients of the liquidity variable seem to be quantitatively small, they sufficiently reflect, the effects of inefficient management of liquidity in the absence of stronger interbank reallocation of surplus liquidity. Maintaining a very high ratio in recent years (cash in vault, required reserves, and low-yielding short-term assets) would have resulted in higher net interest margins.

A positive correlation was found between the ratio of loan loss provisions and total loans that is measure of credit quality. Improving awareness and legal procedures for billing credit with good accounting standards as a function of better risk assessment would help reduce this ratio.

Poor connection and the negative trend were determined in the estimated coefficient for market concentration. This indicates that the system is uncompetitive with respect to the banks; they are the only institutions that offer credit conditions in underdeveloped financial markets and alternative lenders. A possible explanation is that larger banks have lower costs due to economies of scale and that they better serve borrowers in addition to having a larger market share. Smaller banks do not have access to resources as 
larger bank that are branches of international banks, and must offer higher interest rates to attract more deposits and lend to poorer quality clients to achieve higher rates of interest and cover the cost of expensive sources of funds.

Funding risk can be a significant determinant of net interest margin. The high and growing loan - to deposit ratio, the funded ratio of the parent bank can exert pressure on subsidiaries. This was the result after 2008 when the banking sector of $\mathrm{BH}$ and its parent banks suffered from the global financial crisis, which was reflected in the withdrawal of funds from daughter banks, and thus foreign liabilities reduced by half. Loan- to-deposit ratio in banks in $\mathrm{BH}$ has worsened since the banks own $13 \%$ of loans in 2013 was financed by loans, which are the most expensive sources of funds and subsidized loans to a special purpose provide by state-owned Investment and Development Bank of the Republic of Srpska.

In terms of correlation between net interest margin and the consumer price index results are mixed. According to Pineda D. (2010) inflation rate is statistically significant with positive values to the net interest margin and is not negligible in size. According to Huybens E. and Smith B, (1999), inflation exacerbates information asymmetry, and, therefore, leads to higher interest margins.

Economic growth has no significant impact on the interest margin. During the pronounced economic growth in $\mathrm{BH}$ bank loans are almost quadrupled .Interest rates were quite high in line with the high-interest rates on European financial markets. After the start of the economic slowdown and stagnation after a record breaking year in 2008 there was no significant lowering of interest rates on loans. Given that sector of the population uses only slightly less than the loan business privately owned commercial banks charge the highest interest rates on retail loans and deposits at the lowest citizens who are the dominant source of long-term loans. In this way banks as monopolistic institutions retaining a high level of interest margin.

\section{Conclusions}

This paper analyzes the determinants of the net interest margin of the banking sector in BH in the period between 2008 and 2013, using multiple linear regression models. In the quantitative analysis, it is assumed that the net interest margin of the banking sector in $\mathrm{BH}$ (NIM) is used as dependent variable, and the following ones as independent variables: liquidity risk (LR), 
operating costs $(\mathrm{OC})$, credit risk (CR), the index of market concentration $(\mathrm{HHI})$, funding risk (FR), the growth rate of gross domestic product (RGDP) and consumer price index (CPI).The null hypothesis was rejected because it was not shown that the independent variables affect the dependent variable.

The operating costs are the most important determinant of net interest margins of banks. The results of the research led to the conclusion that high reserves for potential credit losses and the ratio of liquid assets affect net interest margins. In terms of specific variables such as inflation uncertainty as to which banks face, was found to be a significant determinant of high-interest margins.

As predicted in the empirical model, all explanatory variables, except the concentration level and real GDP growth, have the expected effects on bank net interest margins. The variable banking concentration is negative and statistically there is a significant increase in banking concentration because an increase in bank concentration does not lead to a decrease in interest margins. In terms of specific variables such as inflation uncertainty as to which banks face, was found to be a significant determinant of high-interest margins. The growth of GDP does not have significant effect on net interest margin of the banks in $\mathrm{BH}$.

Weak private companies in the business sector as well as over-indebtedness affects companies that weaker banks have to take poor borrowers while most big banks lend to high-quality customers. Smaller banks with weaker performance, just to obtain funds, pay higher interest rates and thus must charge higher interest rates on loans and increased interest margin.

The observed period is characterized by the reduction in net interest margins of banks over the previous decade, which was characterized by high GDP growth, bank loans and high-interest rates and high profitability. Smaller banks with weaker performance, just to obtain funds, pay higher interest rates and thus must charge higher interest rates on loans and increased interest margin. Structural reforms, improving the legal and judicial system, better accounting standards, transparent operations, eliminating information asymmetry may enhance the efficiency of financial intermediation of banks in $\mathrm{BH}$. Future research on this topic can be expanded depending on the availability of the database, so that the use of more appropriate explanatory variables for a longer period can get even better analysis. 
Plakalović N., Alihodžić A.: Determinants of the Net Interest Margins in BH Banks

\section{References}

Afanasieff T.S. Lhacer P.M.V., Nakane I.M. (2002). The Determinants of Bank Interest Spread in Brasil, Banko Central do Brasil, Working PaperSeries, No.46, p. 1-32.

Ahokpossi C, (2013). "Determinants of Bank Interest Margins in Sub-Saharian Africa", IMF Working Paper, January, WP/13/34, p. 1-20.

Audit Reports for banks, (2012). Banking Agency of Republic of Srpska, Retrieved from: http://www.abrs.ba/

Banking Agency of Federation of Bosnia and Herzegovina (2013). Information on the banking system of the Federation of $\mathrm{BiH}$, Retrieved from: http://www.fba.ba

Banking Agency of the Republic of Srpska, (2013). Report on the state of the banking system of the Republic of Srpska,Retrieved from: http://www.abrs.ba

Beck T. Demirgüç-Kunt A. Levine R. (2009). Financial Institution and Market across Countries and over Time, Data and Analysis, Policy Research Working Paper, No. 4943, World Bank Development Research Group, May, p.1-43.

CarbóS.V., Rodríguez, F.F. (2007). The Determinants of Banks Margins in European Banking, Journal of Banking and Finance, No.31, p. 2043-2063.

Central Bank of Bosnia and Herzegovina (2012). Annual Report, Retrieved from: http:// www.cbbih.ba

Claeys, S., Vander Vennet R. (2008). Determinants of Bank Interest Margins in Central and Eastern Europe: A Comparison with West, Economic Systems, No.32, p. 197-216.

Demirgüç-Kunt A., Huizinga, H. (1999). Determinants of Commercial Bank Interest Margins and Profitability: Some International Evidence, Worl Bank Economic Review, Vol.13 (2), p. 379-408.

Demirgüç-Kunt A., LaevenL. Levine R. (2003). Regulation, Market Structure, Institutions and Cost of Financial Intermediation, NBER Working paper, No. 9890, August, p. 1-63.

Huybens, E., Smith, B. (1999). Inflation, financial markets, and long-run real activity, Journal of Monetary Economics, No. 43, p. 283-315.

Klein, M. (1971). A theory of the Banking Firm, Journal of Money, Credit and Banking, No. 3, p. 205-18.

Kosmidou, K. (2008). The determinants of bank's profit in Greece during the period of EU financial integration. Managerial Finance, No. 34 (3), p. 146 - 159.

Krunic, G. (2014). Moral hazard and protection mechanisms in the banking sector of Bosnia and Herzegovina, Faculty of Economics, University of Banja Luka, master work.

Nassar, B.K. Martinez, E., Pineda A. (2014). Determinants for Bank's Net Interest Margins in Honduras, Working Paper, IMF, WP/14/163, p. 1-26.

Plakalovic, N. (2011). Financial (il) Literacy and Stability of Financial System, Make Learn, International Conference, Celje, p. 113-120.

Plakalovic, N. (2014). Analysis of interest margin in the domestic banking, The Significance and Role of Accounting, Auditing and Finance in the Process of Economic Recovery, 18th International Congress, Banja Vrućica, September, 1820. pp. 349-372., Retrieved from: http:// www.srrrs.org

Poghosyan T. (2012). Financial Intermediation Costs in Low Income Countries: The Role of Regulatory, Institutional, and Macroeconomic Factors, IMF Working Paper, WP 12/140, p. 1-34. 
Plakalović N., Alihodžić A.: Determinants of the Net Interest Margins in BH Banks

Saunders A..Schumacher, L., (2000) "The Determinants of Bank Interest Rate Margins: An International Study", Journal of Money and Finance, No. 19, p. 813832.

Sensarma R., Ghosh, S (2004), "Net Interest Margin: Does Owneship Matter? VIKALPA, Volume 29 (1), January-March, p. 41-47.

The Wikipedia (2015). Herindahl index http://en.wikipedia.org/wiki/Herfindahl index\#Formula 